\title{
एक 今月の症例
}

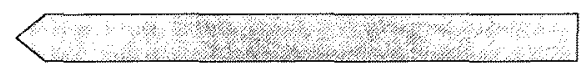

長期インターフェロン $\alpha$ 療法中に溶血性尿毒症症候群類似の

腎病変を合併した慢性骨髄性白血病の 1 例

\author{
東京慈恵会医科大学内科学講座第二 \\ 小林英之 宇都宮保典 宮崎陽一 徳留悟朗 \\ 川村哲也 橋本隆男 酒井 紀 \\ 東京大学医科学研究所内科 高橋 聡 東條有伸 浅野茂隆
}

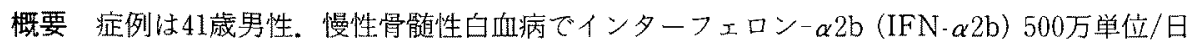
の投与を受け，39力月後に蛋白层が，55力月後には腎機能障害が出現し，漸次堌喜した，66力 月後, $\mathrm{Ccr}$ は $44 \mathrm{ml} / \mathrm{min}$ と低下し, 一日1g前後の蛋白尿, 血小板減少およびハプトグロビンの低 值を認めた。腎生檢所見から本例の腎障害に溶血性尿毒症症候群類似の細小血管レベルでの内 皮細胞障害の関与が示唆され，原因としてIFN- $\alpha$ の関与が強く疑われた。
\end{abstract}

(日内会誌 $86 ： 1259 \sim 1261 ， 1997$ )

Key words : インターフェロンー $\alpha$, 溶血性尿毒症症候群, 慢性骨䯣性白血病, 腎障害

\section{はじめに}

血液疾患抢よびウイルス性肝炎のインターフェ ロン(IFN) 療法中に腎障害を合併することが報告 されている.今回我々は慢性骨髄性白血病 (CML) の長期IFN療法中に溶血性尿毒症症候群 (HUS) 類似の腎障害を認めた症例を経験した。本例の腎 病変の形成にはIFNの関与が強く示唆され, 興味 ある症例と考光，報告する。

$$
\text { 症例 }
$$

患者：41歳, 男性. 主訴：蛋白尿. 既往歴： 特記事項なし。現病歴：1990年 3 月CMLと䛦断 された。同年 7 月より他医でIFN- $\alpha 500$ 万単位/日 の投与が開始された。1993年11月から蛋白尿が出 現し，1995年 2 月に尿蛋白增加と血清クレアチニ ン值上昇を認め, 精查目的で同年12月当科入院し た. 入院時現症：血珐 $116 / 60 \mathrm{mmHg}$, 体温 $36.5^{\circ} \mathrm{C}$, 意識清明, 皮㓺紫斑なし。眼瞼結膜貧血 なし、表在リンパ節触知せず，胸腹部身体所見異 常なし.下腿浮腫なし. 神経学的異常所見なし。

検査所見：末梢血検查では白血球数, 分画に異 常なく, $\mathrm{Hb} 11.7 \mathrm{~g} / \mathrm{dl}$ と軽度の貧血と血小板減少

〔平成 8 年 6 月 8 日 第447回関東地力会推薦〕
(Plt 7.5万/ $/$ l) を認めたが, 破䂥赤血球は認めな かった。凝固系検查ではPA-IgGが34.1ng/107 cells と軽度上昇を認めるのみで他に異常所見を 認めなかった。尿検查では一日1g前後の蛋白尿と 顆粒円柱 $(2+)$, 硝子円柱 $(1+)$ を認めたが, 血 氺は認めなかった。腎機能検查では Ccr $44 \mathrm{ml} /$ $\min$ と中等度の腎機能障害と尿中 $\beta 2$-マイクログ ロブリンが $9360 \mu \mathrm{g} / \mathrm{l}$ 異常高值を認めた。血清学 的検查でハプトグロビン $(\mathrm{Hp})$ 值が $9 \mathrm{mg} / \mathrm{d} l$ 以下で あったがクームステストおよび自己抗体は㓌性 であった、腹部エコーでは肝臓、脾臓の軽度腫大, 腎実質エコーレベルの上昇を認めた。眼底所見は H1S1であった. 臨床経過：入院後, 第 5 病日に 経皮的腎生検を施行した. 光学顕微鏡所見では総 系球体数 7 個のうち球状硬化は認められず，糸球 体では末梢係蹄壁の二層化，内皮細胞の腫大（図 1)が湤漫性に認められ，一部の系球体ではメサ ンギウム融解, 毛細血管内に血栓形成を認めた。 さらに, 中等度の㽷細管萎縮とりンパ球を主体と した間質の細胞浸潤ならびに線維化を認めた。血 管系では細動脈内皮下腔の浮腫性拡大を諗めた。

一方, 免疫組織学的所見では, 系球体に免疫グロ ブリン, 補体の有意な沈着は認められなかった。 


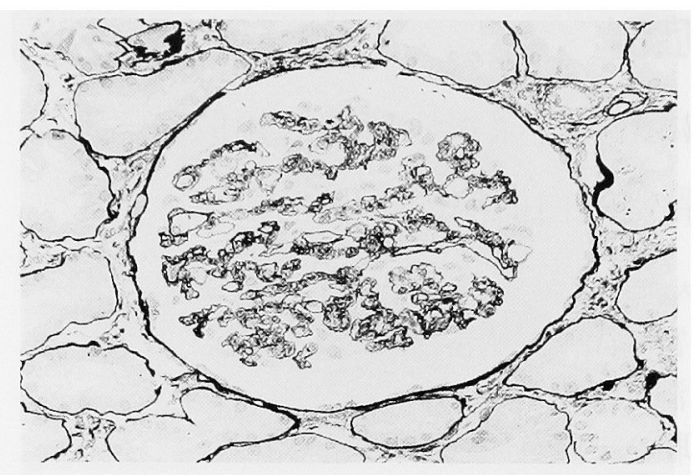

図 1。系球体組織所見 $(P A M, \times 200)$ ，系球体係蹄壁 の二層化を認める.

腎生検後，本例の腎障害に対し副腎皮質ステロイ ド薬と抗血小板薬の投与を開始したところ尿蛋白 の著明な減少と腎機能の改善を認めた（図 2 ).

\section{考 察}

IFNによる腎障害に関する従来の検討では，血 液疾患抢よびウイルス性肝炎のIFN療法施行中に 約 $15 \%$ 症例で蛋白尿の出現が認められること， また組織学的には血栓性細小血管障害, 微小変化 型ネフローゼ，もしくは急性尿細管壞死に一致す る病理像を呈すること（など）が報告されてい
る ${ }^{1-5)}$.これら腎病変の成因にはIFNの関与が考え られており，その発症にはIFNの投与期間あるい は投与量が重要であることが示唆されている。す なわち300〜 500万単位/日で15〜20力月以上の長 期投与例が多く，末期腎不全に陥った症例も認め られている。一方, IFNによる腎障害の機序は未だ 明らかではないが，IFN一抗IFN抗体による免疫 複合体が形成され，これが系球体に扝けるケモ力 イン産生を誘導すること, あるいはNK細胞を介 して腎組織障害を惹起するなどの免疫学的機序が 想定されている6). 本例における腎障害には腎組 織所見および血小板減少, 血清 $\mathrm{Hp}$ の低下などの検 查所見より, HUS類似の病態が関与している可能 性が示唆された。本例では八イドロキシウレアを 投与している，現在までにハイドロキシウレアに よる腎病変の合併報告はない. また，CMLは慢性 期にあり，その時期での特異的腎病変の合併報告 もないことから本例のHUS類似腎病変の形成に はIFNの関与が強く考えられた，本例ではステロ イドと抗血小板薬の併用療法後に腎機能の改善と 蛋白尿の減少が認められており，IFNが免疫担当 細胞および様々なサイトカインを介し内皮細胞障 害を惹起し，末梢係蹄壁の二層化や血栓形成など

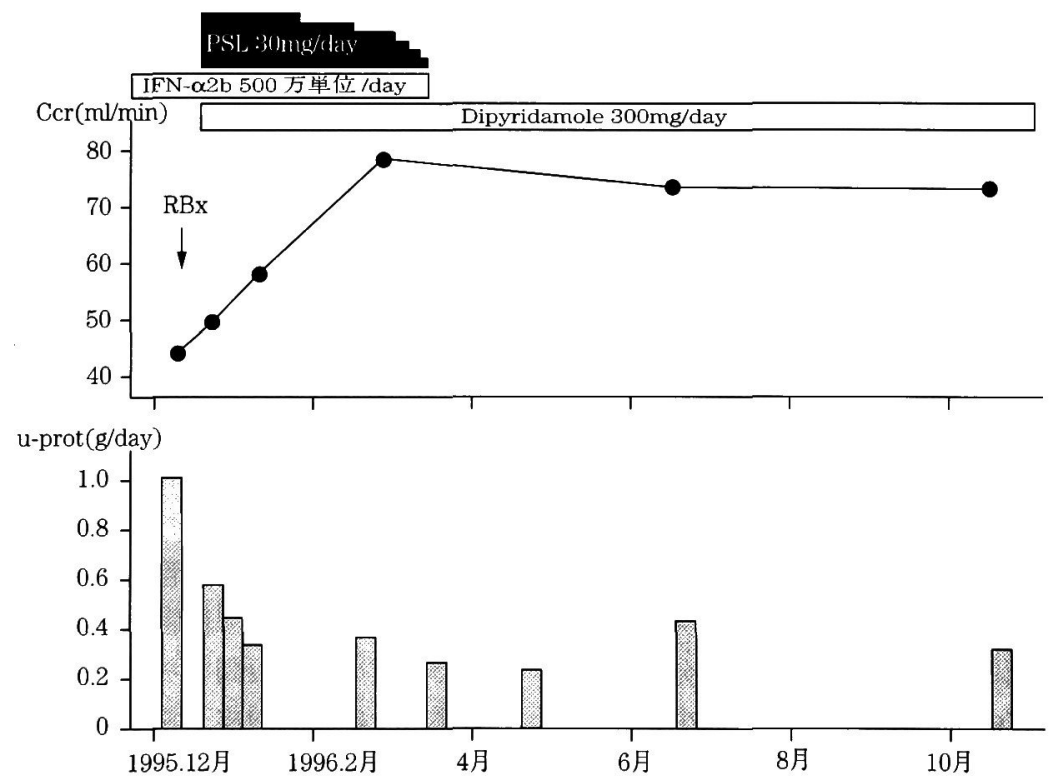

図 2. 臨床経過 
のHUS類似の腎病変をきたした可能性が考えら れた。今後,種々な疾患へのIFN治療に際しては腎 障害の合併に留意し，腎機能ならびに尿検查など 注意深い経過観察が必要と考光られた。

\section{文献}

1) Jadoul M, et al: Renal thrombotic microangiopathy in patients with chronic myelogenous leukaemia treated with interferon $\alpha 2 \mathrm{~b}$. Nephrol Dial Transplant 10: 111, 1995.

2) Lederer $E$, Truong $L$ : Unusual glomerular lesion in a patient receiving long.term interferon alpha. Am J Kid Disease 20:516, 1992.

3) Traynor A, et al: Minimal-change glomer- ulopathy and glomerular visceral epithelial hyperplasia associated with alpha-interferon therapy for cutaneous T-cell lymphoma. Nephron 67: 94, 1994.

4) Schlaifer D, et al: Hemolytic-uremic syndrome in a patient with chronic myelogenous leukemia treated with interferon alpha. Am J Hematol 47: 254, 1994.

5) Harvey $M$, et al: Recombinant interferon alpha and hemolytic uremic syndrome: Cause or coincidence? Am J Hematol 46: 152, 1994.

6) Phillips TM: Interferon- $\alpha$ induces renal dysfunction and injury. Current Opinion in Nephrology and Hypertension 5:380, 1996. 